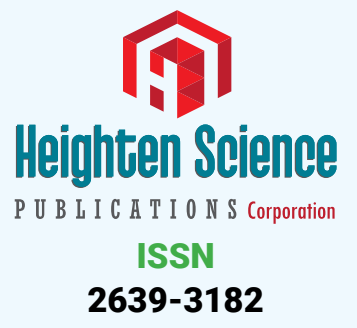

*Address for Correspondence: Amitis Ramezani, Hepatitis, AIDS and Blood Borne Diseases Department, Pasteur Institute of Iran, 13164, Pasteur Ave., Tehran, Iran, Tel: +982164112812; Fax: +982164112812:

Email: amitisramezani@hotmail.com

Submitted: 12 December 2018

Approved: 18 December 2018

Published: 19 December 2018

Copyright: (c) 2018 Larijani MS, et al. This is an open access article distributed under the Creative Commons Attribution License, which permits unrestricted use, distribution, and reproduction in any medium, provided the original work is properly cited

D) Check for updates
Mini Review

\section{HIV-1 Immune evasion: The main obstacle toward a successful vaccine}

\author{
Mona Sadat Larijani, Seyed Mehdi Sadat and Amitis Ramezani* \\ Hepatitis, AIDS and Blood Borne Diseases Department, Pasteur Institute of Iran, Tehran, Iran
}

It is estimated that there are 36.9 million individuals living with HIV-1 from who 21.7 million patients receiving antiretroviral therapy (ART) [1,2]. ART has had a significant effect on the patients' quality of life recently, however, its global coverage declines to $16-35 \%$ in low or middle income parts of Africa [3]. ART is unable to eliminate the virus from the infected individuals despite the fact of great impact on virus life cycle. There is no doubt that vaccination is considered as the most important medical strategy to prevent and suppress the infectious diseases. Nevertheless, there are many difficulties toward the cure or prevention of HIV-1 including the virus characteristics, lack of ideal animal model and funding [4-7].

As the infection is caused by HIV-1, a burst of viremia happens and consequently specific CD8+ and CD4+ T cells are generated. Consequently, the viral load decreases according to T-cell mediated pathway and antibodies can be detectable by six months after infection [8-10]. The virus is capable to escape from human immune system recognition due to its genetically variable glycoprotein on the envelope and also diverse virus protein products which can effect on the host cell cycle [11,12]. HIV-1 genome encodes Gag, Pol and Env as its three main proteins and also some accessory proteins in an open reading frame. Each of these proteins acts differently among the virus establishment in host cell and also immune evasion. The ability of genetic diversity of HIV-1 is one of the crucial immune evasion approaches for the virus. The HIV-1 RNA genome is capable of mutation randomly which contributes to evade the host immune recognition. All HIV-1 products have been widely investigated toward achieving an effective vaccine candidate [13-15].

The virus enters through the mucosal surfaces of genital tissues during sexual transmission. Indeed mucosa is the first line of physical defense against the pathogens.

One of the proposed mechanisms to avoid this barrier is that HIV-1 crosses the mucosal surface by capturing intraepithelial DCs $[16,17]$. Moreover, the tight junction proteinsand the integrity of the monolayer mucosal epitheliummight be disrupted according to the exposure of the viral protein gp120 (processed by Env) and due to the upregulating inflammatory cytokines which then leads to the increase of virus particles permeability. HIV-1 establishes acute infection in present immune cells within the mucosa following mucosal breaking step from which the resting $\mathrm{CD}^{+} \mathrm{T}$ cells are the main targets $[17,18]$. After penetration of the mucosal barrier, a major host defense mechanism is conferred by complement system which contributes to the restriction of viral replication by bursting plasma membranes of undesired cellsand also recruitment of inflammatory cells. Despite this, HIV-1 is able to overcome the complement mediated response by activating the classical pathway of complement system by ability of envelope protein gp41 binding. Capsid or p24, a Gag product, also contributes to immune evasion by hiding HIV-1 nucleic in order to mimic the cellular proteins [19-23]. 
Moreover, Cytokines and chemokines have significant impact on HIV-1 pathogenesis since the infection results in the activation of NK cells, macrophages, DCs, and the activation of B cells. Attachment of HIV-1 envelope protein through gp120 provokes the production of CC chemokines which are chemoattractants for lymphocytes, DCs and macrophages. In addition to main HIV-1 proteins, HIV-1 uses different mechanisms to escape this cytokine networks by its accessory products $[14,20]$. For instance, HIV1 Tat (transactivator of transcription) protein imitates $\beta$-chemokines and that leads to increased activation and infection. Furthermore, Nef (HIV-1 negative regulatory factor) leads to rise of production and the stimulatory function of proinflammatory cytokines such as IL-12 and IL-15. Nef also it is the main protein which downregulates HLA-A and HLA-B on target cells and inhibits the cytotoxicity of NK cells $[15,17]$.

The interaction between this intelligent virusand the host cells is complicated. The host system attempts to use its machinery to overcome HIV-1 infection progression, whereas the virus manipulates the host tools to its own propagation. By looking at clinical trials, many kinds of vaccines have been investigated including protein, peptide and DNA or RNA based vaccines which try to make use of the most important HIV-1 products in order to recall immune system. Although neither of them has been successful. Indeed, a therapeutic vaccine against HIV-1 is a priority with the aim of eliminating the virus from cells due to this fact that transmission of it is preventable and possible. Therefore, understanding of the way that HIV-1 overcomes host immune defense and targeting the virus products which are more conserved among different clades and are crucial for the virus life cycle will improve our knowledge toward developing a therapeutic approach to HIV-1 infection and spreading.

\section{References}

1. HIV/AIDS fact sheet: World Health Organization 2017; Ref.: https://goo.gl/8Wuxhk

2. Sidibé M. UNAIDS DATA 2017. Joint United Nations Programme on HIV/AIDS (UNAIDS); 2017; Ref.: https://goo.gl/U7641S

3. Barry SM, Lora AJM, Novak RM. Trial, Error, and Breakthrough: A Review of HIV Vaccine Development. AIDS Clin Res. 2014; 5: 359. Ref.: https://goo.gl/4pPrLz

4. Hütter GND, Mossner M, Ganepola S, Müssig A, Allers K, et al. Long-term control of HIV by CCR5 Delta32/ Delta32 stem-cell transplantation. N Engl J Med. 2009; 360: 692-698. Ref.: https://goo.gl/E4qunw

5. Taylor BS, Hammer SM. The challenge of HIV-1 subtype diversity. N Engl J Med. 2008; 359:19651966. Ref.: https://goo.gl/FgT14G

6. Richman DD, Wrin T, Little SJ, Petropoulos $C J$. Rapid evolution of the neutralizing antibody response to HIV type 1 infection. Proc Natl Acad Sci U S A. 2003;100: 4144-4149. Ref.: https://goo.gl/89SNDg

7. Koup RA, Safrit JT, Cao Y, Andrews CA, McLeod G, et al. Temporal association of cellular immune responses with the initial control of viremia in primary human immunodeficiency virus type 1 syndrome. J Virol. 1994; 68: 4650-4655. Ref.: https://goo.gl/FHYMRv

8. Maartens G, Celum C, Lewin SR. HIV infection: epidemiology, pathogenesis, treatment, and prevention. Lancet. 2014; 384: 258-271. Ref.: https://goo.gl/4HvPZ4

9. Tanser F, Bärnighausen T, Grapsa E, Zaidi J, Newell ML. High coverage of ART associated with decline in risk of HIV acquisition in rural KwaZulu-Natal, South Africa. Science. 2013; 339: 966-971. Ref.: https://goo.gl/TJe3n3

10. Finzi D, Blankson J, Siliciano JD, Margolick JB, Chadwick K, et al. Latent infection of CD4+ T cells provides a mechanism for lifelong persistence of HIV-1, even in patients on effective combination therapy Nat Med 1999; 5: 512-517. Ref.: https://goo.gl/bVadxx

11. Corey L, Gilbert PB, Tomaras GD, Haynes BF, Pantaleo G, et al. Immune correlates of vaccine protection against HIV-1 acquisition. Sci TransI Med. 2015; 7: 310. Ref.: https://goo.gl/RRWWRe

12. Rappuoli R, Aderem A. A 2020 vision for vaccines against HIV, tuberculosis and malaria. Nature. 2011; 473: 463-469. Ref.: https://goo.gl/76NKfh

13. Hearps AC, Jans DA. Regulating the functions of the HIV-1 matrix protein. AIDS research and human retroviruses. 2007; 23: 341-346. Ref.: https://goo.gl/fjrqG6 
14. Frankel AD, Young JA. HIV-1: fifteen proteins and an RNA. Annual review of biochemistry. 1998; 67: 1-25. Ref.: https://goo.gl/UnKhha

15. Rolland M. HIV-1 immune evasion-a threat to effective vaccines? Nat Med. 2016; 7; 22: 580-581. Ref.: https://goo.gl/WVjzVr

16. Malim MH, Emerman M. HIV-1 accessory proteinsensuring viral survival in a hostile environment. Cell Host and Microbe. 2008; 3: 388-398. Ref.: https://goo.gl/fK2mhV

17. Guha D, Ayyavoo V. Innate Immune Evasion Strategies by Human Immunodeficiency Virus Type 1. Hindawi Publishing Corporation. 2013: 1-10. Ref.: https://goo.gl/cz7kgs

18. Goto $T$, Kennel SJ, Abe M, Takishita $M$, Kosaka $M$, et al. A novelmembrane antigen selectively expressed on terminally differentiated human B cells. Blood. 1994; 84: 1922-1930,. Ref.: https://goo.gl/HDsvqL

19. McMichael AJ, Borrow P, Tomaras GD, Goonetilleke N, Haynes BF. The immune response during acute HIV-1 infection: clues for vaccine development. Nature Reviews Immunology Letters. 2010; 10: 11-23. Ref.: https://goo.gl/FX6jxc

20. Agrati C, D'Offizi G, Gougeon ML, Malkovsky M, Sacchi A, et al. Innate gamma/delta T-cells during HIV infection: terra relatively incognita in novel vaccination strategies? AIDS Reviews. 2011; 13: 3-12. Ref.: https://goo.gl/KpPjM4

21. Keele BF, Giorgi EE, Salazar-Gonzalez JF, Decker JM, Pham KT, et al. Identification and characterization of transmitted and early founder virus envelopes in primary HIV-1 infection. Proc Natl Acad Sci U S A. 2008; 105: 7552-7557. Ref.: https://goo.gl/hQko8y

22. Zhang Y, Li J, Li Q. Immune Evasion of Enteroviruses Under Innate Immune Monitoring. Front Microbiol. 2018; 14; 9: 1866. Ref.: https://goo.gl/zyUEjs

23. Ringel $O$, Vieillard V, Debré $P$, Eichler J, Büning H, et al. The Hard Way towards an Antibody-Based HIV1 Env Vaccine: Lessons from Other Viruses. Viruses. 2018; 15: 10. E197. Ref.: https://goo.gl/opGgDn 